\title{
Passage through the rumen and the large intestine of sheep estimated from faecal marker excretion curves and slaughter trials
}

\author{
A. de Vega*, J. Gasa†, C. Castrillo and J. A. Guada \\ Departamento de Producción Animal y Ciencia de los Alimentos, Facultad de Veterinaria, Miguel Servet 177, \\ 50013 Zaragoza, Spain
}

(Received 30 October 1997 - Revised 24 February 1998 - Accepted 27 April 1998)

\begin{abstract}
External digesta markers (Yb-labelled diets and Co-EDTA) were given orally as a pulse dose to four pairs of Rasa Aragonesa twin ewe lambs, fed on either chopped or ground and pelleted lucerne hay, in order to estimate slow $\left(k_{1}\right)$ and fast $\left(k_{2}\right)$ rates of passage of liquid and solid phase from faecal marker excretion curves. After the faecal sampling period daily doses of the same markers were infused continuously for $5 \mathrm{~d}$ and the animals slaughtered. Concentrations of markers in the different compartments of the gut were determined and used to calculate mean retention times. The results showed that the rumen and the large intestine were the two main mixing compartments of the gut, accounting for more than $95 \%$ of total mean retention time. Rates of passage estimated from faecal marker excretion did not accurately represent marker kinetics in the compartments of the gut derived from slaughter data. Accuracy in the estimation of fractional outflow rate from rumen $\left(k_{\mathrm{R}}\right)$ by $k_{1}$ was higher for low values of $k_{\mathrm{R}}$ whereas $k_{2}$ consistently overestimated large intestine outflow rate $\left(k_{\mathrm{LI}}\right)$, especially for high values of $k_{\mathrm{R}}$. The relationship between outflow rates from the main two mixing compartments was important in influencing the accuracy of prediction of faecal estimates.
\end{abstract}

Rate of passage: Gastrointestinal tract: Sheep

Retention time of digesta in the different compartments of the ruminant gut, especially the ruminoreticulum, is one of the most important factors affecting the extent and site of digestion, and consequently the amounts and types of nutrients actually reaching the duodenum (Ellis, 1978). In addition, retention time is important when determining the physical regulation of voluntary intake (Ulyatt et al. 1986).

The direct measurement of digesta flow is laborious and generally involves the use of surgically modified animals; obtaining representative samples of rumen digesta is often difficult, especially from animals fed on forages in the long form (Mansbridge \& Ørskov, 1980). The alternative approach, involving markers and mathematical models, has the potential for a more adequate description of the overall process and for delineating possible causal mechanisms; however, it also has the potential for errors in interpretation if the requirements of the approach are not met or the assumptions involved are not understood (Ellis et al. 1984). In this respect there is still a lack of agreement in the interpretation of kinetic parameters obtained from faecal marker excretion curves (Blaxter et al. 1956; Grovum \& Williams, 1973; Ellis et al. 1979; Dhanoa et al. 1985).
In the present experiment, comparisons were made between outflow rates obtained from faecal marker excretion or from slaughter trials, and the reasons for discrepancies analysed. Preliminary results have already been presented as either posters or oral communications (Gasa et al. 1993; de Vega et al. 1994a,b).

\section{Materials and methods \\ Animals and diets}

Eight 11-month-old Rasa Aragonesa twin lamb ewes, averaging 33.6 (SE 0.75) kg live weight, were allocated to one of two diets of lucerne (Medicago sativa) hay either chopped $(50 \mathrm{~mm}$; diet $\mathrm{C})$ or ground $(2 \mathrm{~mm})$ and pelleted $(\operatorname{diet} \mathrm{P})$. Intake was restricted to $90 \%$ of previously established $\mathrm{ad}$ libitum values and diets were offered in twelve daily meals. Chemical composition of both diets is shown in Table 1 .

Animals were kept in individual metabolic cages during the digestibility trial and the faecal sampling period, and in individual stands, bedded on sawdust, during the rest of the experiment. They had free access to water and mineral

\footnotetext{
Abbreviations: LP, lignin permanganate; TMRT, total mean retention time; TT, transit time.

*Corresponding author: Dr A. de Vega, fax +34767615 90, email avega@ posta.unizar.es

$\dagger$ Present address: Departament de Producció Animal, Universitat Autònoma de Barcelona, Bellaterra 18193, Barcelona, Spain.
} 
Table 1. DM ( $\mathrm{g} / \mathrm{kg})$ and chemical composition $(\mathrm{g} / \mathrm{kg} \mathrm{DM})$ of the diets

\begin{tabular}{lcc}
\hline & $\begin{array}{c}\text { Chopped } \\
\text { lucerne hay }\end{array}$ & $\begin{array}{c}\text { Pelleted } \\
\text { lucerne hay }\end{array}$ \\
\hline DM & 847 & 877 \\
Organic matter & 857 & 832 \\
Nitrogen & $31 \cdot 5$ & $29 \cdot 1$ \\
Ether extract & 22 & 24 \\
Neutral-detergent fibre & 457 & 431 \\
Acid-detergent fibre & 315 & 312 \\
Lignin permanganate & 89 & 75 \\
\hline
\end{tabular}

blocks. At 1 month before the experimental period the animals were treated orally against internal parasites with Thiabendazol.

\section{Experimental procedure}

The experiment lasted for $40 \mathrm{~d}$ of which the first $14 \mathrm{~d}$ were for adaptation and measurement of voluntary intake. The sheep were then placed in metabolic cages, fed at $90 \%$ ad libitum and after $3 \mathrm{~d}$, a $7 \mathrm{~d}$ digestibility trial was performed.

Once the animals were back in the standings, and after a $3 \mathrm{~d}$ resting period, they were given pulse doses of $10 \mathrm{~g} \mathrm{Yb}$ labelled diets and $50 \mathrm{ml}$ of a solution containing $0.5 \mathrm{~g}$ of CoEDTA. Labelled diets were orally dosed with the aid of a $50 \mathrm{ml}$ plastic syringe barrel. Labelled diet $\mathrm{C}$ was previously chopped down with scissors to a size of about $5 \mathrm{~mm}$. The Co-EDTA solution was orally introduced with the aid of a $10 \mathrm{ml}$ plastic syringe. Bulk faecal samples were taken at 3 , $4 \cdot 5,6,7 \cdot 5,9,12,15,18,21,24,28,33,39,48,58,72,120$ and $144 \mathrm{~h}$ post dose to construct the faecal marker excretion curves.

After a $2 \mathrm{~d}$ rest period, and for five consecutive days, daily doses of $6 \mathrm{~g} \mathrm{Yb}$-labelled diets and $60 \mathrm{ml}$ of a solution containing $0 \cdot 2 \mathrm{~g}$ of Co-EDTA were administered in twelve equal portions at feeding time to mimic a continuous infusion. Lignin was also used as internal marker. Three faecal samples were taken at 3,9 and $21 \mathrm{~h}$ on the fifth day of marker administration to check for steady-state conditions of external markers, and the following morning animals were slaughtered, after administration of a sedative-analgesic. The gut was removed and separated into ruminoreticulum, omasum, abomasum, small intestine, caecum, ascending colon and a fraction including transverse colon, descending colon and rectum. Digesta contents were weighed and sampled for chemical composition, particle size and marker analysis. As marker concentration did not differ among the different fractions of the hindgut it was considered as a single mixing compartment, hereafter referred to as the large intestine.

\section{Marker techniques}

Co-EDTA was prepared according to the technique developed by Udèn et al. (1980), and the Yb-labelled diets by soaking the forages in a buffer of acetate solution $(0 \cdot 1 \mathrm{M}$ acetic acid adjusted to $\mathrm{pH} 6.0$ with $\mathrm{NH}_{4} \mathrm{OH}$ ) for $3 \mathrm{~h}$ and then overnight in the same solution containing $17 \mathrm{mg}$ of ytterbium acetate $/ \mathrm{kg}$ DM. The labelled material was washed several times with distilled water and allowed to dry.
Digesta and faecal samples were dried at $105^{\circ}$ for $24 \mathrm{~h}$, ground to pass through a $1 \mathrm{~mm}$ screen and analysed for marker concentrations by adding $15 \mathrm{ml} 1.5 \mathrm{M}-\mathrm{HNO}_{3}+$ $0.027 \mathrm{M}-\mathrm{KCl}$ and $5 \mathrm{ml} 7 \mathrm{M}-\mathrm{HClO}_{4}$ to the ashed $\left(550^{\circ}\right.$ for $\left.8 \mathrm{~h}\right)$ material. After boiling gently for $3 \mathrm{~min}$, samples were filtered and marker concentrations determined by atomic emission spectrometry using a Perkin-Elmer P-40 spectrophotometer (Perkin Elmer, Uberlingen, Germany).

Faecal marker excretion curves were fitted to the multicompartmental model developed by Dhanoa et al. (1985), which was restricted to two compartments as the rumen and the caecum are assumed to be the main functional mixing pools of the gut. This model consists of a multiplicative equation which includes single and double exponential terms:

$$
\mathrm{y}=\mathrm{Ae}^{-\mathrm{c}_{1} \mathrm{t}} \exp \left[-\mathrm{Be}^{-\mathrm{c}_{2} \mathrm{t}}\right],
$$

where $\mathrm{A}, \mathrm{B}, \mathrm{c}_{1}\left(k_{1}\right)$ and $\mathrm{c}_{2}\left(k_{2}-k_{1}\right)$ are parameters estimated by iterative procedures. In the model $k_{1}$ and $k_{2}$ are estimates of the outflow rate of digesta through the rumen and the large intestine, although not necessarily in that order. Estimates of transit time (TT) and total mean retention time (TMRT) were also calculated as

$$
\mathrm{TT}=\sum_{\mathrm{i}=3}^{\mathrm{N}-1} \frac{1}{k_{2}+(\mathrm{i}-2)\left(k_{2}-k_{1}\right)}
$$

and

$\operatorname{TMRT}=1 / k_{1}+1 / k_{2}+\sum_{\mathrm{i}=3}^{\mathrm{N}-1} \frac{1}{k_{2}+(\mathrm{i}-2)\left(k_{2}-k_{1}\right)}, \quad k_{2}>k_{1}$.

Model fitting was performed using a DEC VAX/750 computer and the MLP statistical package (Ross, 1987).

Outflow rates from the different compartments of the digestive tract in the slaughter trial were estimated according to the procedures described by Faichney (1975), using the equation

$$
\mathrm{K}=\mathrm{F} / \mathrm{Q},
$$

where $\mathrm{K}$ represents the fractional outflow rate $(/ \mathrm{h})$ from the compartment, $\mathrm{F}$ the rate of administration of markers $(\mathrm{mg} / \mathrm{h})$ and $\mathrm{Q}$ the amount of marker (mg) actually present in the compartment, calculated as

$$
\mathrm{Q}=\mathrm{C} \times \mathrm{A} \text {, }
$$

where $\mathrm{C}$ represents the concentration of markers in the digesta at steady-state conditions (mg/g DM) and A the amount of DM $(\mathrm{g})$ in the pool considered.

\section{Chemical analysis}

The DM content of each feed and digesta sample was determined by oven drying at $105^{\circ}$ for $24 \mathrm{~h}$, and organic matter in the diets by ashing at $550^{\circ}$ for $8 \mathrm{~h}$. Total $\mathrm{N}$ was determined by the Kjeldahl method. Neutral-detergent fibre, acid-detergent fibre and lignin permanganate (LP) were measured on dried samples according to the method of Goering \& Van Soest (1970). Ether extract was determined by the method of the Association of Official Agricultural Chemists (1985). 


\section{Particle size analysis}

The particle size distribution of the contents of the different compartments of the gastrointestinal tract (rumen, reticulum, omasum, abomasum, small intestine and large intestine) was determined using a wet-sieving apparatus as described by Evans et al. (1973). Sieve sizes were chosen in a geometric progression (Kennedy, 1984), being of $0 \cdot 15$, $0 \cdot 30,0 \cdot 60,1 \cdot 20$ and $2 \cdot 40 \mathrm{~mm}$ (length of side of square hole). Between 15 and $65 \mathrm{~g}$ digesta (about $5 \mathrm{~g} \mathrm{DM}$ ) was thoroughly dispersed in about $200 \mathrm{ml}$ water and washed onto the top sieve of the apparatus. Water flow was set at 4.85 litres/min and the apparatus was run for $5 \mathrm{~min}$. The sieves were then inspected so that any clumps of particles could be dispersed and the apparatus was run for another $5 \mathrm{~min}$. Particles retained on each sieve were collected onto tared filter papers and dried at $70^{\circ}$ for $48 \mathrm{~h}$. The dry weights were expressed as a percentage of the total DM in the sieved sample.

Mean particle size was estimated following the procedures described by Pond et al. (1984) where the calculated value indicates the size of the theoretical sieve which retains $50 \%$ of the particles.

\section{Statistical analysis}

Intake and digestibilities, and whole digesta, DM, organic matter, acid-detergent fibre, and LP contents in the different compartments of the gut were analysed by means of oneway ANOVA following the methods proposed by Steel \& Torrie (1980). Differences in digesta weights between diets were analysed separately for each compartment of the gut.

Mean particle size of the digesta contents of the different compartments was analysed as a split-plot, with animals as the main plot and gut compartment the subplot.

Faecal marker excretion data and outflow rates through each compartment of the gut were analysed as a split-plot design, animal being the main plot and marker the subplot.

The intake of one of the animals on diet $\mathrm{C}$ during the continuous marker infusion period was significantly lower than during the previous period, hence it was removed from the analysis and treated as a missing value.

Significant differences between treatment means were compared by the least significant difference test.

Faecal marker parameters $k_{1}$ and $k_{2}$ were compared with slaughter-derived passage rates through the rumen and large intestine respectively, by means of paired $t$ tests.

\section{Results}

Mean daily intakes and digestibility coefficients are shown in Table 2. Average DM intake was not significantly affected by the physical form of the forage, although intakes of diet $\mathrm{P}$ tended to be larger. During continuous administration of markers, intake was slightly lower than planned (65.5 and $88.3 \mathrm{~g} \mathrm{DM} / \mathrm{kg}$ metabolic weight $\left(\mathrm{W}^{0 \cdot 75}\right)$ for diets $\mathrm{C}$ and $P$ respectively), probably due to the stress caused to the animals. On the other hand digestibility coefficients were significantly larger on diet $\mathrm{C}$ for crude protein $(P<0.001)$, DM $(P<0.01)$ and organic matter $(P<0.05)$ but not for neutral-detergent fibre $(P>0.05)$.
Table 2. DM intake ( $\mathrm{g} / \mathrm{kg}$ live weight $\left.{ }^{0.75}\right)$, and DM, organic matter $(\mathrm{OM})$, crude protein (CP), and neutral-detergent fibre (NDF) digestibility coefficients (\%) of lucerne hay which was chopped (C) or ground and pelleted $(P)$, during the digestibility trials

(Mean values for four sheep)

\begin{tabular}{lcccrc}
\hline & $\mathrm{C}$ & $\mathrm{P}$ & $\mathrm{SE}(6 \mathrm{df})$ & \multicolumn{1}{c}{$F$} & $P$ \\
\hline DM intake & 71.8 & 94.3 & 8.58 & 3.44 & 0.1130 \\
Digestibility & & & & & \\
DM & 53.5 & $47 \cdot 1$ & 1.22 & 14.03 & 0.0096 \\
OM & 54.0 & 48.7 & 1.41 & 6.95 & 0.0387 \\
CP & $68 \cdot 8$ & $58 \cdot 7$ & 0.67 & 114.75 & 0.0001 \\
NDF & 32.8 & 32.3 & 3.45 & 0.01 & 0.9175 \\
\hline
\end{tabular}

Table 3. Weights (g) of whole digesta (WD), DM, organic matter $(\mathrm{OM})$, acid-detergent fibre (ADF) and lignin permanganate (LP) in the different compartments of the digestive tract of animals consuming lucerne hay which was chopped $(\mathrm{C})$ or ground and pelleted $(\mathrm{P})$

\begin{tabular}{lrrr}
\hline & $C$ & $P$ & Residual SD* \\
\hline Rumen & & & \\
WD & 4190 & 3529 & $842 \cdot 6$ \\
DM & 748 & 616 & $200 \cdot 5$ \\
OM & 668 & 547 & $181 \cdot 9$ \\
ADF & 341 & 271 & $77 \cdot 4$ \\
LP & 131 & 106 & $30 \cdot 6$ \\
Omasum & & & \\
WD & 117 & 106 & $42 \cdot 0$ \\
DM & 25 & 23 & $9 \cdot 8$ \\
OM & 22 & 24 & $6 \cdot 6$ \\
ADF & 11 & 12 & $3 \cdot 7$ \\
LP & 4 & 4 & $2 \cdot 0$ \\
Abomasum & & & \\
WD & 185 & 192 & $85 \cdot 0$ \\
DM & 20 & 19 & $9 \cdot 5$ \\
OM & 18 & 19 & $6 \cdot 8$ \\
ADF & 9 & 8 & $3 \cdot 9$ \\
LP & 4 & 3 & $1 \cdot 5$ \\
Large intestine & & & \\
WD & 765 & 916 & $311 \cdot 3$ \\
DM & 130 & 207 & $50 \cdot 1$ \\
OM & 110 & 168 & $42 \cdot 2$ \\
ADF & 55 & 80 & $22 \cdot 3$ \\
LP & 20 & 31 & $8 \cdot 9$ \\
\hline
\end{tabular}

*There was one missing value.

Table 4. Mean particle size $(\mathrm{mm})$ of digesta in the different compartments of the digestive tract of animals consuming lucerne hay which was chopped $(\mathrm{C})$ or ground and pelleted $(\mathrm{P})$

\begin{tabular}{lcccc}
\hline & $\mathrm{C}$ & $\mathrm{P}$ & Mean & $\begin{array}{c}\text { Residual SD } \\
(21 \mathrm{df})^{*}\end{array}$ \\
\hline Reticulum & $0.81^{\mathrm{a}}$ & $0.45^{\mathrm{a}}$ & 0.63 & \\
Rumen & $0.86^{\mathrm{a}}$ & $0.45^{\mathrm{a}}$ & 0.65 & \\
Omasum & $0.29^{\mathrm{b}}$ & $0.29^{\mathrm{c}}$ & 0.29 & $0.031 \dagger$ \\
Abomasum & $0.30^{\mathrm{b}}$ & $0.36^{\mathrm{b}}$ & 0.33 & \\
Small intestine & $0.27^{\mathrm{b}}$ & $0.29^{\mathrm{c}}$ & 0.28 & \\
Large intestine & $0.25^{\mathrm{b}}$ & $0.26^{\mathrm{c}}$ & 0.25 & \\
$\quad$ Mean & 0.46 & 0.35 & & \\
Residual SD (5 df) & \multicolumn{2}{c}{$0.083 \ddagger$} \\
\hline
\end{tabular}

$\overline{\mathrm{a}, \mathrm{b}, \mathrm{c}}$ Values in the same column with unlike superscript letters were significantly different $(P<0.05)$. For differences between diets within each compartment see pp. 381-383.

* There were ten missing values.

† For comparisons between gut compartments, between diets within each gut compartment and between gut compartments within each diet.

‡ For comparisons between diets. 

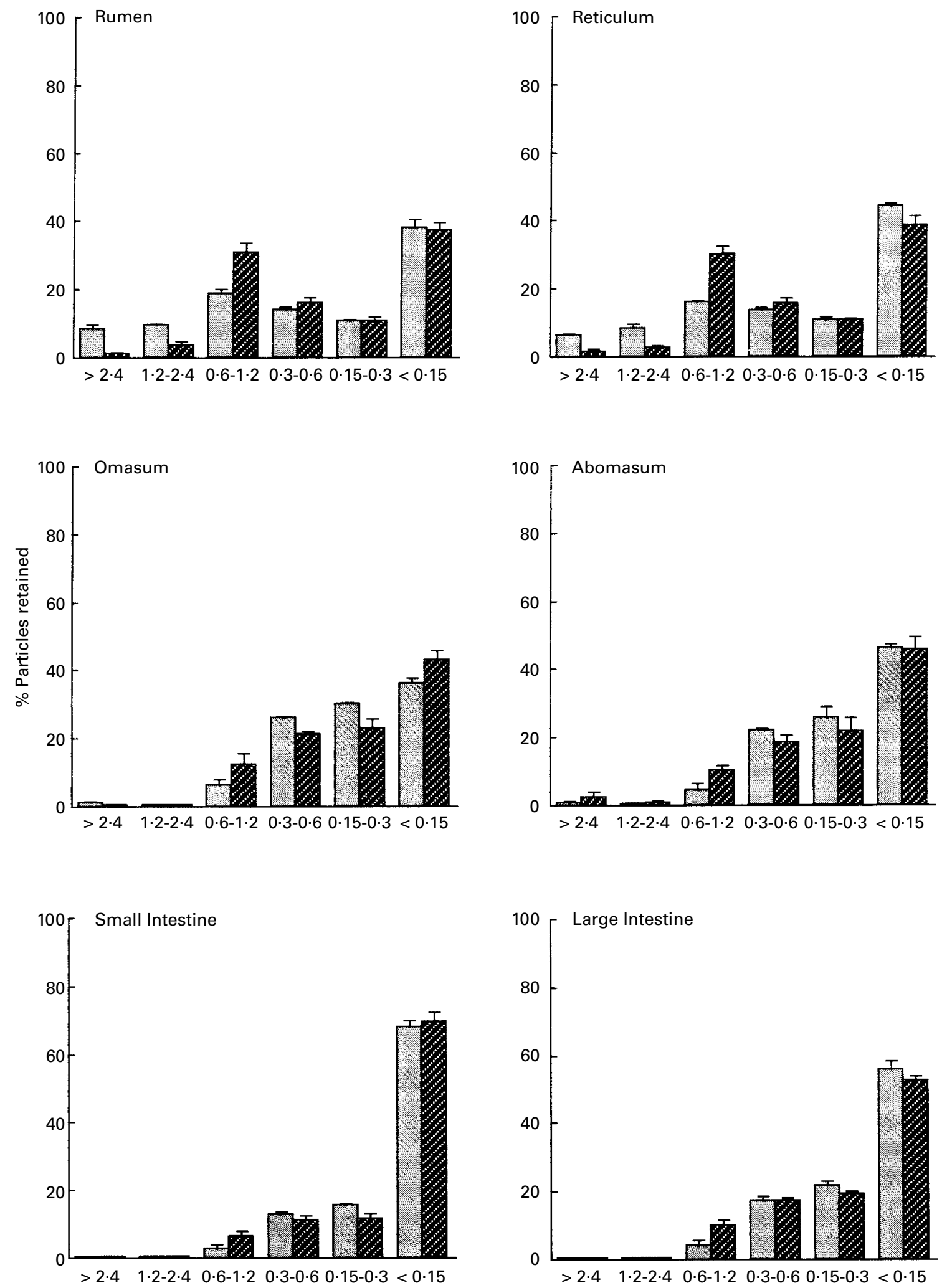

Particle size $(\mathrm{mm})$

Fig. 1. Particle size distribution within the different compartments of the gut from sheep fed on lucerne hay which was chopped (国) or ground and pelleted $(\mathbb{Q})$. 
Table 5. Slow $\left(k_{1}\right)$ and fast $\left(k_{2}\right)$ fractional outflow rates $(/ \mathrm{h})$, transit time (TT; h) and total mean retention time (TMRT; $h$ ) of cobalt-EDTA (Co) and ytterbium-labelled diets $(\mathrm{Yb})$ in animals consuming lucerne hay which was chopped $(C)$ or ground and pelleted $(P)$ (Mean values for four sheep)

\begin{tabular}{|c|c|c|c|c|c|}
\hline & $\mathrm{C}$ & $\mathrm{P}$ & Mean & SE $(6 \mathrm{df})^{*}$ & $P$ \\
\hline \multicolumn{6}{|l|}{$k_{1}$} \\
\hline Co & 0.054 & 0.080 & $0 \cdot 067^{a}$ & \multirow{3}{*}{0.0029} & \multirow{3}{*}{0.0102} \\
\hline $\mathrm{Yb}$ & 0.045 & 0.059 & $0 \cdot 052^{b}$ & & \\
\hline Mean & 0.050 & 0.069 & & & \\
\hline SE $(6 \mathrm{df}) \dagger$ & \multicolumn{2}{|c|}{0.0070} & & & \\
\hline$P$ & \multicolumn{2}{|c|}{0.0901} & & & \\
\hline \multicolumn{6}{|l|}{$k_{2}$} \\
\hline Co & 0.475 & 0.648 & 0.562 & \multirow{5}{*}{0.0517} & \multirow{5}{*}{0.0568} \\
\hline $\mathrm{Yb}$ & $0 \cdot 301$ & 0.479 & 0.390 & & \\
\hline Mean & 0.388 & 0.564 & & & \\
\hline SE $(6 \mathrm{df}) \dagger$ & \multirow{2}{*}{\multicolumn{2}{|c|}{$\begin{array}{l}0.0776 \\
0.1608\end{array}$}} & & & \\
\hline$P$ & & & & & \\
\hline \multicolumn{6}{|l|}{ TT } \\
\hline Co & $6 \cdot 4$ & $6 \cdot 5$ & $6 \cdot 5^{\mathrm{a}}$ & \multirow{3}{*}{$0 \cdot 38$} & \multirow{3}{*}{0.0027} \\
\hline $\mathrm{Yb}$ & $10 \cdot 2$ & $8 \cdot 0$ & $9 \cdot 1^{b}$ & & \\
\hline Mean & $8 \cdot 3$ & $7 \cdot 3$ & & & \\
\hline SE (6 df)† & \multirow{2}{*}{\multicolumn{2}{|c|}{$\begin{array}{l}0.94 \\
0.4498\end{array}$}} & & \multirow{7}{*}{$1 \cdot 31$} & \multirow{7}{*}{0.0045} \\
\hline$P$ & & & & & \\
\hline \multicolumn{6}{|l|}{ TMRT } \\
\hline Co & $29 \cdot 0$ & $21 \cdot 3$ & $25 \cdot 2^{a}$ & & \\
\hline $\mathrm{Yb}$ & $39 \cdot 4$ & $27 \cdot 4$ & $33 \cdot 4^{b}$ & & \\
\hline Mean & $34 \cdot 2$ & $24 \cdot 3$ & & & \\
\hline SE $(6 \mathrm{df}) \dagger$ & \multirow{2}{*}{\multicolumn{2}{|c|}{$\begin{array}{l}4 \cdot 68 \\
0 \cdot 1863\end{array}$}} & & & \\
\hline$P$ & & & & & \\
\hline
\end{tabular}

${ }^{a, b}$ Mean values within a category with unlike superscript letters were significantly different $(P<0.05)$.

${ }^{*}$ For comparisons between markers.

†For comparisons between diets.
The weights of the rumen, omasum, abomasum and large intestine contents were not significantly affected by diet type (Table 3 ), whereas mean particle size was significantly affected by the interaction diet $\times$ gut compartment (Table 4 ). Particle size of digesta was larger in animals fed on diet $\mathrm{C}$ for the reticulum and the rumen $(P<0.001)$, with no statistically significant differences between diets for the other compartments. For diet $\mathrm{C}$ there were no differences in mean particle size from omasum onwards, whereas for diet $\mathrm{P}$ abomasum showed values lower than for ruminoreticulum but higher than for omasum, small intestine and large intestine, with no differences between the latter compartments. The model used for statistical analysis of particle size data proved satisfactory $(P=0 \cdot 0001)$. The particle size distribution within each compartment of the gut is shown in Fig. 1.

Fractional outflow rates $\left(k_{1}, k_{2}\right)$, TT and TMRT of CoEDTA and Yb-labelled diets, estimated from faecal marker excretion curves, are presented in Table 5. Grinding and pelleting tended to increase rate of passage of both markers although differences were not significant. Estimates of TT and TMRT were not affected by diet although TMRT tended to be higher on diet C. Co-EDTA showed faster rates of passage and shorter TT, and consequently shorter TMRT than Yb-labelled diets $(P<0 \cdot 01)$. The split-plot model explained most of the variability in TMRT $(P=0.0022)$, TT $(P=0.0113)$ and $k_{1}(P=0.0088)$.

The concentration of markers in the three faecal samples taken the day before slaughter did not change with time as shown by the regression coefficient values which were not

Table 6. Fractional outflow rates $(/ \mathrm{h})$ from the ruminoreticulum $\left(k_{\mathrm{R}}\right)$, omasum $\left(k_{\mathrm{O}}\right)$, abomasum $\left(k_{\mathrm{A}}\right)$ and large intestine $\left(k_{\mathrm{LI}}\right)$ of cobalt-EDTA $(\mathrm{Co})$, ytterbium-labelled diets $(\mathrm{Yb})$ and lignin permanganate (LP) in sheep consuming lucerne hay which was chopped $(\mathrm{C})$ or ground and pelleted $(\mathrm{P})$

\begin{tabular}{|c|c|c|c|c|}
\hline & $\mathrm{C}$ & $\mathrm{P}$ & Mean & Residual SD \\
\hline \multicolumn{5}{|l|}{$k_{\mathrm{R}}$} \\
\hline Co & 0.073 & $0 \cdot 162$ & $0 \cdot 117$ & \\
\hline $\mathrm{Yb}$ & 0.041 & 0.068 & 0.054 & $0.0117(10 \mathrm{df})^{\star}$ \\
\hline LP & 0.024 & 0.045 & 0.035 & \\
\hline Mean & 0.046 & 0.092 & & \\
\hline Residual SD (5 df)† & \multicolumn{2}{|c|}{0.0359} & & \\
\hline \multicolumn{5}{|l|}{$k_{0}$} \\
\hline Co & 1.964 & $5 \cdot 666$ & $3 \cdot 815$ & \multirow{5}{*}{$2 \cdot 0293(9 \mathrm{df}) \ddagger$} \\
\hline $\mathrm{Yb}$ & $1 \cdot 168$ & $1 \cdot 864$ & 1.516 & \\
\hline LP & 0.934 & 3.072 & $2 \cdot 003$ & \\
\hline Mean & $1 \cdot 355$ & 3.534 & & \\
\hline Residual SD (5 df)† & \multicolumn{2}{|c|}{4.2631} & & \\
\hline \multicolumn{5}{|l|}{ - } \\
\hline Co & 3.297 & $6 \cdot 075$ & $4 \cdot 686$ & \multirow{4}{*}{$1 \cdot 7738(9 \mathrm{df}) \neq$} \\
\hline $\mathrm{Yb}$ & $2 \cdot 617$ & $2 \cdot 675$ & $2 \cdot 646$ & \\
\hline LP & $1 \cdot 318$ & $3 \cdot 404$ & $2 \cdot 361$ & \\
\hline Mean & $2 \cdot 411$ & $4 \cdot 051$ & & \\
\hline Residual SD (5 df)† & \multicolumn{2}{|c|}{$4 \cdot 7639$} & & \\
\hline \multicolumn{5}{|l|}{$k_{\mathrm{LI}}$} \\
\hline Co & $0 \cdot 142$ & $0 \cdot 148$ & $0 \cdot 145$ & \multirow{5}{*}{$0.0221(10 \mathrm{df}) \ddagger$} \\
\hline $\mathrm{Yb}$ & $0 \cdot 166$ & $0 \cdot 138$ & $0 \cdot 152$ & \\
\hline LP & $0 \cdot 180$ & $0 \cdot 149$ & $0 \cdot 165$ & \\
\hline Mean & $0 \cdot 163$ & $0 \cdot 145$ & & \\
\hline Residual SD (5 df) $\dagger$ & \multicolumn{2}{|c|}{0.0846} & & \\
\hline
\end{tabular}

\footnotetext{
* For comparisons between markers, between diets within each marker and between markers within each diet.

†For comparisons between diets.

‡For comparisons between markers.
} 
different from zero $(P>0 \cdot 1)$. From these results steadystate conditions were assumed.

The outflow rates from ruminoreticulum $\left(k_{\mathrm{R}}\right)$, omasum $\left(k_{\mathrm{O}}\right)$, abomasum $\left(k_{\mathrm{A}}\right)$ and large intestine $\left(k_{\mathrm{LI}}\right)$ of Co-EDTA, Yb-labelled diets and LP estimated at slaughter are presented in Table 6. The ruminoreticulum and the large intestine were shown to be the main mixing compartments, the cumulative retention time in these two pools $\left(1 / k_{\mathrm{R}}+1 / k_{\mathrm{LI}}\right)$ accounting for more than $95 \%$ of the mean retention time in the four mixing compartments of the gut $\left(1 / k_{\mathrm{R}}+1 / k_{\mathrm{O}}+1 / k_{\mathrm{A}}+1 / k_{\mathrm{LI}}\right)$. Rumen outflow rates of all markers were significantly increased by grinding and pelleting, but the highest values were recorded with Co-EDTA. Differences between $\mathrm{Yb}$-labelled particles and LP were significant only for diet P. Large intestine outflow rate was independent of both marker and diet type and, except for Co-EDTA on diet $\mathrm{P}(P>0.05)$, was always faster than rumen outflow rate $(P<0 \cdot 05)$. The model used for statistical analysis of the data was adequate for all the parameters considered $\left(P=0.0001\right.$ for $k_{\mathrm{R}}, P=0.0321$ for $k_{\mathrm{O}}$, $P=0.0096$ for $k_{\mathrm{A}}$ and $P=0.0013$ for $k_{\mathrm{LI}}$ ).

As shown in Fig. 2, mean retention time in the two main mixing compartments of the gut $\left(1 / k_{\mathrm{R}}+1 / k_{\mathrm{LI}}\right)$ was not accurately represented by faecal marker excretion parameters $\left(1 / k_{1}+1 / k_{2}\right)$, low mean retention time values being generally overestimated and high values generally underestimated by faecal outflow rates. The regression coefficient of $1 / k_{1}+1 / k_{2} v \cdot 1 / k_{\mathrm{R}}+1 / k_{\mathrm{LI}}$ was $0.99(y=-0 \cdot 29+0 \cdot 99 x$; $\left.r^{2} 0.62 ; P<0.001\right)$, although when data from the ewe which presented the higest values of $1 / k_{1}+1 / k_{2}$ were removed the coefficient became $0 \cdot 38(y=10 \cdot 40+0 \cdot 38 x$; $\left.r^{2} 0.71 ; P<0.001\right)$. As shown in Fig. 3 increasing values of $k_{\mathrm{R}}$ were reflected in increasing values of $k_{1}$ although generally to a lesser extent. There was no significant difference

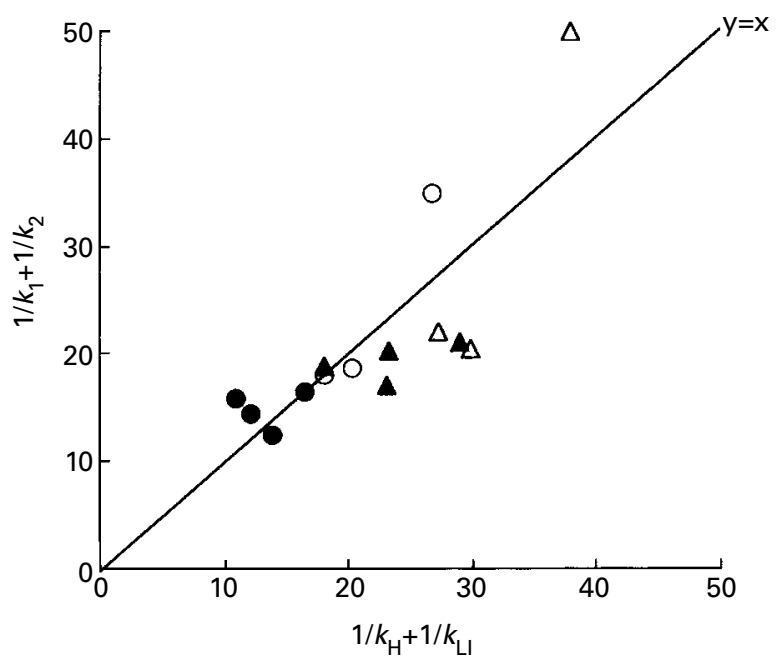

Fig. 2. Relationship between retention time in rumen and large intestine estimated from slaughter data $\left(1 / k_{\mathrm{R}}+1 / k_{\mathrm{LI}}\right)$ and faecal marker excretion curves $\left(1 / k_{1}+1 / k_{2}\right)$, as affected by diet (lucerne hay which was chopped $(O, \Delta)$ or ground and pelleted $(\bullet, \Delta))$ and indicated by marker (cobalt-EDTA $(\mathrm{O}, \boldsymbol{\bullet})$ or ytterbium-labelled diets $(\triangle, \mathbf{\Delta}))$. For details of regression analysis, see p. 386.

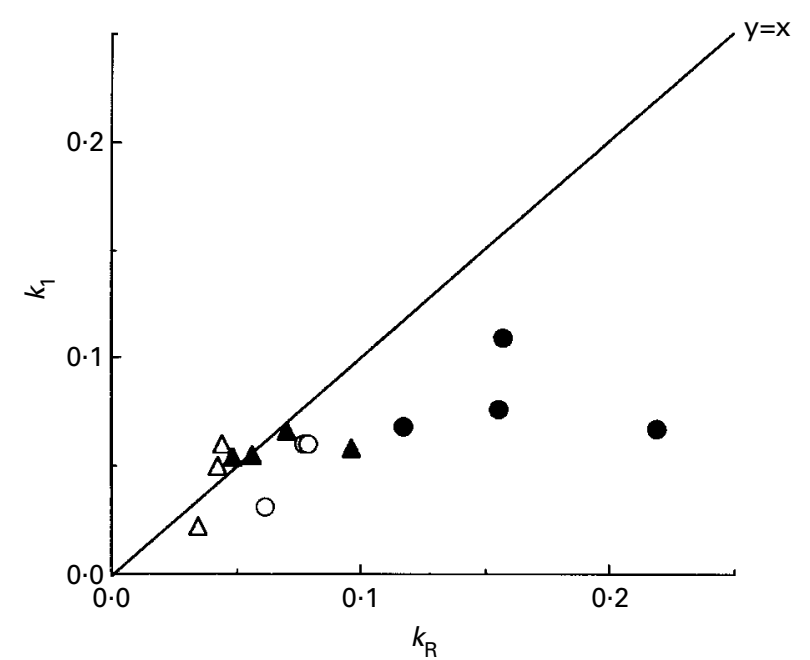

Fig. 3. Relationship between fractional outflow rate from the rumen estimated from slaughter samples $\left(k_{R}\right)$ and from faecal marker excretion curves $\left(k_{1}\right)$, as affected by diet (lucerne hay which was chopped $(O, \Delta)$ or ground and pelleted $(\boldsymbol{\bullet}, \Delta))$ and indicated by marker (cobalt-EDTA $(\bigcirc, \bullet)$ or ytterbium-labelled diets $(\triangle, \mathbf{\Lambda})$ ).

$(t 0 \cdot 27 ; 10 \mathrm{df})$ between the regression coefficients for $\mathrm{Yb}$ labelled diets $\left(k_{1}=0 \cdot 03+0 \cdot 38 k_{\mathrm{R}} ; r^{2} 0 \cdot 31 ; P=0 \cdot 1919\right)$ and Co-EDTA $\left(k_{1}=0 \cdot 04+0 \cdot 24 k_{\mathrm{R}} ; r^{2} 0 \cdot 33 ; P=0 \cdot 1795\right)$ in the relationship between $k_{\mathrm{R}}$ and $k_{1}$. The values of $k_{\mathrm{R}}$ were significantly higher than $k_{1}$ for Co-EDTA $(P<0.05$ for both diets $\mathrm{C}$ and $\mathrm{P}$ ) but not for Yb-labelled particles $(P>0 \cdot 1)$. Differences were larger for diet $\mathrm{P}$ as a result of the higher outflow rates recorded with this diet. By contrast, and as shown in Fig. $4, k_{\mathrm{LI}}$ values were always higher than $k_{2}$, for both Co-EDTA $(P<0.05$ for both diets $\mathrm{C}$ and $\mathrm{P})$ and

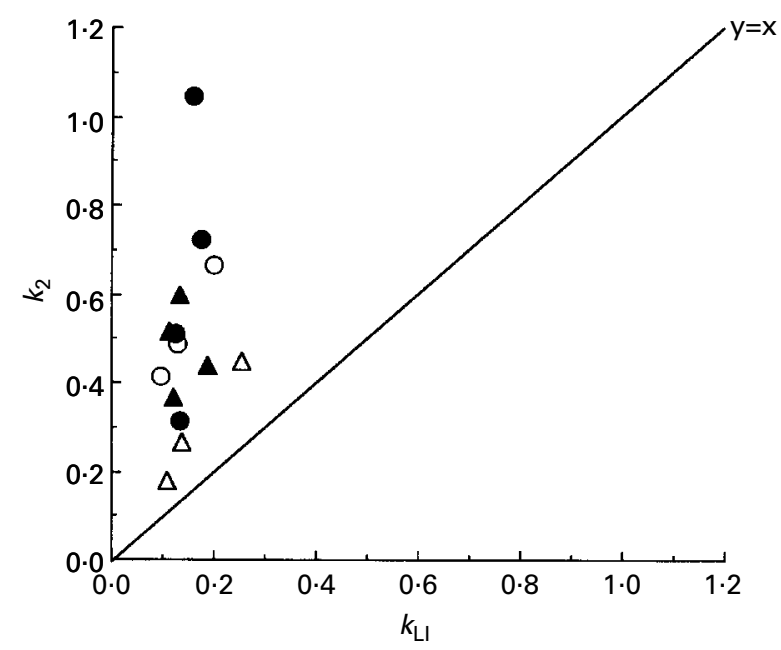

Fig. 4. Relationship between fractional outflow rate from the large intestine estimated from slaughter samples $\left(k_{\mathrm{LI}}\right)$ and from faecal marker excretion curves $\left(k_{2}\right)$, as affected by diet (lucerne hay which was chopped $(O, \Delta)$ or ground and pelleted $(\boldsymbol{\bullet}, \mathbf{\Delta}))$ and indicated by marker (cobalt-EDTA $(\mathrm{O}, \boldsymbol{\bullet})$ or ytterbium-labelled diets $(\triangle, \boldsymbol{\Lambda})$ ). 
Yb-labelled particles $(P<0 \cdot 1$ and $P<0 \cdot 01$ for diets $\mathrm{C}$ and $P$ respectively).

\section{Discussion}

Diet processing resulted in slight differences in chemical composition, which may be easily explained by selective losses during the grinding and pelleting of the lucerne. A larger DM intake and lower digestibility coefficients, associated with higher rumen outflow rate values were also recorded, as previously shown by Shaver et al. (1986), Woodford \& Murphy (1988) and others.

There was a good relationship between $\mathrm{Yb} k_{\mathrm{R}}$ and $\mathrm{DM}$ intake: $\mathrm{Yb} k_{\mathrm{R}}(\% / \mathrm{h})=-0.48+0.078 \mathrm{DM}$ intake $\left(\mathrm{g} / \mathrm{kg} \mathrm{W}^{0.75}\right.$ per d); $r^{2} 0 \cdot 64 ; P=0 \cdot 0304$, which was not accompanied by differences between diets in rumen load (Table 3). This linear relationship would probably have resulted from dietderived differences in the proportion of particles in the rumen of a size capable of passage through the reticuloomasal orifice (Table 4 and Fig. 1), together with a higher rate and extent of degradation of diet $\mathrm{P}$, and differences in water turnover (Table 6).

As shown in Table 6, the contribution of the large intestine to total tract (excluding the small intestine) mean retention time was higher on diet $\mathrm{P}(51,32$ and $23 \%$ for CoEDTA, Yb-labelled diets and LP respectively) than C (33, 19 and $11 \%$ respectively). The highest values were always recorded with Co-EDTA irrespective of diet. Differences between markers were mainly due to the different values of rumen outflow rate since liquids and solids do not behave independently in the large intestine as shown by Faichney \& Boston (1983) and the present results. Moreover, retention time in both omasum $\left(1 / k_{\mathrm{O}}\right)$ and abomasum $\left(1 / k_{\mathrm{A}}\right)$ was quantitatively of minor importance $(<3 \%)$.

Differences observed between average $k_{\mathrm{R}}$ (Table 6) and average $k_{1}$ (Table 5) were larger than those previously reported by Mira \& MacRae (1982) or Mudgal et al. (1982) but similar to those recorded by Cruickshank et al. (1989) with young lambs fed ad libitum on high-quality forages. These differences were due to the kinetic behaviour of the liquid marker, as $\mathrm{Yb}$-labelled particles showed similar average $k_{\mathrm{R}}$ and $k_{1}(P>0.05)$ for both $\mathrm{C}$ and $\mathrm{P}$ diets.

Similarly, $k_{\mathrm{LI}}$ (Table 6) was largely overestimated by $k_{2}$ (Table 5), this overestimation being greater than that found by Dixon et al. (1982) and Faichney \& Boston (1983). However, in this earlier work $k_{2}$ was estimated by either applying first-order kinetics to caecal samples (Dixon et al. 1982) or by mathematical simulation (Faichney \& Boston, 1983), while in our current experiment $k_{2}$ was derived from the multicompartmental model developed by Dhanoa et al. (1985). This model is known to produce higher $k_{2}$ estimates than other models (Gasa \& Sutton, 1991). Moreover, our $k_{\mathrm{LI}}$ values were estimated with reference to the entire large intestine, and hence may have been underestimated with respect to the values obtained from caecal and proximal colon by the workers previously mentioned.

In a simulation study, Cruickshank et al. (1989) elegantly theorized that the ratio caecal : rumen outflow rates rather than the outflow rate values per se would influence the faecal excretion curve, and would dictate how accurately the excretion curve from the rumen is replicated in faeces. In the present experiment, the relationship $k_{\mathrm{LI}} / k_{\mathrm{R}}$ was also observed to affect the accuracy of $k_{1}$ as an estimate of $k_{\mathrm{R}}$. Cruickshank et al. (1989) estimated rumen outflow rate from duodenal or abomasal marker excretion curves, and caecal outflow rate from simulation, using the model of Grovum \& Williams (1973), and assuming that the parameter was adequately represented by faecal $k_{2}$. The authors themselves pointed out that estimations of rumen outflow rate could be slightly erroneous as a result of the diurnal variation in rumen digesta content observed in grazing sheep and the associated fluctuations in marker concentration. On the other hand, the assumption that caecal outflow rate is adequately described by faecal $k_{2}$ may lead to large errors in its estimation (Ellis et al. 1979 and the present results). Slaughter experiments give more confidence to data used to estimate actual outflow rates, and our results support, experimentally, the suggestion that the caecum-large intestine can modify the faecal marker excretion curve. This leads to biased estimates of rumen outflow rate from faecal $k_{1}$. At high rumen outflow rates, analysis of the descending portion of the faecal marker excretion curve is likely to result in an erroneous estimate as shown to happen with CoEDTA, especially on diet $\mathrm{P}$, where the $k_{\mathrm{LI}} / k_{\mathrm{R}}$ was lower, resulting in severe underestimates of $k_{\mathrm{R}}$ from $k_{1}$.

Cruickshank et al. (1989) suggested that multicompartmental models (Dhanoa et al. 1985) would minimize the bias from the estimate of $k_{\mathrm{R}}$ from $k_{1}$ as these models estimate simultaneously, and not sequentially, the rumen and large intestine outflow rates. However, in our present experiment the multicompartmental model of Dhanoa et al. (1985) did not provide reliable digesta kinetic estimates, and discrepancies between outflow rates estimated from slaughter or faecal marker excretion curves were large for both rumen and large intestine. Moreover, the model was originally developed for values of $k_{2}>k_{1}$, which was not always the case in our experiment. Faichney \& Boston (1983) and Cruickshank et al. (1989), among others, have already reported that the ruminoreticulum may not always have the longest mean retention time, and Dhanoa et al. (1985), describing the multicompartmental model, have stated that 'it fulfills the requirement of providing two rate constants which in theory relate to the two compartments having the longest mean retention time, although it has yet to be demonstrated clearly that they can be identified as the rumen and the caecum'. In our study the largest underestimates of $k_{\mathrm{R}}$ from $k_{1}$ were coincident with the largest overestimates of $k_{\mathrm{LI}}$ from $k_{2}$, as a result of the joint estimation of $k_{1}$ and $k_{2}$ by the model.

The TT calculated from this model (Table 5) also failed to represent retention time in tubular sections of the gut and mixing compartments other than the rumen and the large intestine (Table 6). This suggests that the faecal variable TT may also include events produced in either the ruminoreticulum or the large intestine. In addition, in the model of Dhanoa et al. (1985) TT is obtained from an expression including both $k_{1}$ and $k_{2}$, so misleading estimations of any parameter will give erroneous TT values.

At high outflow rates single-dose markers given orally may well result in a significant proportion of marker reaching the abomasum more rapidly, in turn modifying the faecal marker excretion curve. This is especially so with 
liquid markers as shown by Cafe \& Poppi (1994) who demonstrated that a significant proportion of imbibed water bypasses the rumen to go directly to the abomasum. As a result, multicompartmental models are likely to produce erroneous estimates of transit kinetics of markers through the rumen when their outflow rate is high, although they prove satisfactory for low outflow rates. Events which occurred in the large intestine were not represented at all by faecal $k_{2}$, and the discrepancies were larger also at higher rumen outflow rates. This fact precludes the use of multicompartmental models to estimate $k_{\mathrm{LI}}$, even for low outflow rates. Further research is needed to develop a model to analyse faecal concentration curves accurately. Recent attempts have used multi-compartmental, double-marker models (Aharoni et al. 1994) but their accuracy in estimating rumen and large intestine outflow rates has yet to be checked experimentally for a wide range of diets and animals.

\section{Acknowledgements}

A. de Vega was in receipt of fellowships from the Organization for Economic Co-operation and Development, and 'CAI-CONAI Programa Europa' for a stay at the Institute for Grassland and Environmental Research (IGER, Hurley). Drs J. D. Sutton, M. Gill and J. France, and Mr M. S. Dhanoa are gratefully acknowledged for providing both their wisdom and the facilities of the IGER for particle size analysis and fitting of the faecal marker excretion curves. The skilled technical assistance of Mr Angel Barceló and Miss Ana Esteban is gratefully acknowledged.

\section{References}

Aharoni Y, Brosh A \& Holzer Z (1994) Double marker digestive tract model. Journal of Theoretical Biology 166, 407-417.

Association of Official Agricultural Chemists (1985) Official Methods of Analysis of the Association of Official Agricultural Chemists, 14th ed. Washington, DC: AOAC.

Blaxter KL, Graham NMcC \& Wainman FW (1956) Some observations on the digestibility of food by sheep, and on related problems. British Journal of Nutrition 10, 69-91.

Cafe LM \& Poppi DP (1994) The fate and behaviour of imbibed water in the rumen of cattle. Journal of Agricultural Science, Cambridge 122, 139-144.

Cruickshank GJ, Poppi DP \& Sykes AR (1989) Theoretical considerations in the estimation of rumen fractional outflow rate from various sampling sites in the digestive tract. British Journal of Nutrition 62, 229-239.

de Vega A, Gasa J, Castrillo C \& Guada JA (1994a) Ruminal and hindgut digesta kinetic parameters in sheep estimated from faecal marker excretion and slaughter trials. Annales de Zootechnie 43, Suppl. 1, 33S.

de Vega A, Gasa J, Castrillo C \& Guada JA (1994b) A new approach to the interpretation of rumen and hindgut digesta outflow rate estimations from faecal marker excretion curves. Proceedings of the Society of Nutrition Physiology 3, 57.

Dhanoa MS, Siddons RC, France J \& Gale DL (1985) A multicompartmental model to describe marker excretion patterns in ruminant faeces. British Journal of Nutrition 53, 663-671.

Dixon RM, Nolan JV \& Milligan LP (1982) Studies in the large intestine of sheep. 2. Kinetics of liquid and solid markers in the caecum and proximal colon. British Journal of Nutrition 47, $301-309$.
Ellis WC (1978) Determinants of grazed forage intake and digestibility. Journal of Dairy Science 61, 1828-1840.

Ellis WC, Matis JH \& Lascano C (1979) Quantitating ruminal turnover. Federation Proceedings 38, 2702-2706.

Ellis WC, Matis JH, Pond KR, Lascano CE \& Telford JP (1984) Dietary influences on flow rate and digestive capacity. In Herbivore Nutrition in the Subtropics and Tropics, pp. 269293 [FMC Gilchrist and RI Mackie, editors]. Craighall, South Africa: The Science Press, Ltd.

Evans EW, Pearce GR, Burnett J \& Pillinger SL (1973) Changes in some physical characteristics of the digesta in the reticulorumen of cows fed once daily. British Journal of Nutrition 29, 357376.

Faichney GJ (1975) The use of markers to partition digestion within the gastrointestinal tract of ruminants. In Digestion and Metabolism in the Ruminant, pp. 277-291 [IW McDonald and ACI Warner, editors]. Armidale, Australia: The University of New England Publishing Unit.

Faichney GJ \& Boston RC (1983) Interpretation of the faecal excretion patterns of solute and particle markers introduced into the rumen of sheep. Journal of Agricultural Science, Cambridge 101, 575-581.

Gasa J, de Vega A, Castrillo C, Balcells J \& Guada JA (1993) The behaviour of Co-EDTA and Yb-labelled hay in the gastrointestinal tract of the sheep. Proceedings of the Nutrition Society 52, 178A.

Gasa J \& Sutton JD (1991) Empleo de marcadores en estudios de cinética de paso a través del tracto digestivo de vacas lecheras (The use of markers to study passage kinetics through the digestive tract of dairy cows). Investigación Agraria: Producción y Sanidad Animal 6, 39-50.

Goering HK \& Van Soest PJ (1970) Forage Fiber Analysis. Agricultural Handbook no. 379. Washington, DC: Agricultural Research Service, USDA.

Grovum WL \& Williams VJ (1973) Rate of passage of digesta in sheep. 4. Passage of marker through the alimentary tract and the biological relevance of rate constants derived from the changes in concentration of marker in faeces. British Journal of Nutrition 30, 313-329.

Kennedy PM (1984) Summary and conclusions from discussion. In Techniques in Particle Size Analysis of Feed and Digesta in Ruminants, pp. 184-186 [PM Kennedy, editor]. Edmonton, Canada: Canadian Society of Animal Science.

Mansbridge RJ \& Ørskov ER (1980) Measurement and factors affecting outflow rates of protein supplements in sheep and cattle. Animal Production 30, 486-487.

Mira JJF \& MacRae JC (1982) Comparison of rumen and faecal sampling procedures of calculating the retention time of digesta markers in the rumen of steers. Proceedings of the Nutrition Society 41, 77A.

Mudgal VD, Dixon RM, Kennedy PM \& Milligan LP (1982) Effect of two intake levels on retention time of liquid, particle and microbial markers in the rumen of sheep. Journal of Animal Science 54, 1051-1055.

Pond KR, Tolley EA, Ellis WC \& Matis JH (1984) A method for describing the weight distribution of particles from sieved forage. In Techniques in Particle Size Analysis of Feed and Digesta in Ruminants, pp. 123-133 [PM Kennedy, editor]. Edmonton, Canada: Canadian Society of Animal Science.

Ross GJS (1987) MLP: Maximum Likelihood Program (A Manual). Oxford: Numerical Algorithms Group Ltd.

Shaver RD, Nytes AJ, Satter LD \& Jorgensen NA (1986) Influence of amount of feed intake and forage physical form on digestion and passage of prebloom alfalfa hay in dairy cows. Journal of Dairy Science 69, 1545-1559.

Steel RGD \& Torrie JH (1980) Principles and Procedures of Statistics. New York, NY: McGraw Hill Book Company Inc. 
Udèn P, Colucci PE \& Van Soest PJ (1980) Investigation of chromium, cerium and cobalt as markers in digesta. Rate of passage studies. Journal of the Science of Food and Agriculture 31, 625-632.

Ulyatt MJ, Dellow DW, John A, Reid CSW \& Waghorn GC (1986) Contribution of chewing during eating and rumination to the clearance of digesta from the ruminoreticulum. In Control of
Digestion and Metabolism in Ruminants, pp. 498-515 [LP Milligan, WL Grovum and A Dobson, editors]. Englewood Cliffs, NJ: Prentice-Hall.

Woodford ST \& Murphy MR (1988) Effect of forage physical form on chewing activity, dry matter intake and rumen function of dairy cows in early lactation. Journal of Dairy Science 71, 674686. 


\title{
The Nutrition of Goats
}

\author{
AFRC Technical Committee on Responses to Nutrients, Report No. 10
}

This report is a comprehensive review of published information on the body composition and digestive physiology of temperate zone goats, the composition of their products, meat, milk and fibre, their voluntary feed intake, and their associated energy, protein, mineral and vitamin requirements. The systematic approach is similar to that of earlier reviews of ruminant nutrient requirements published by the Agricultural Research Council in 1980 and 1984, which are factorial in nature. In particular the energy and protein requirements are expressed in terms of Metabolisable Energy (ARC 1980, AFRC 1990) and Metabolisable Protein (AFRC1992), using the models for cattle and sheep as appropriate. The requirements for calcium and phosphorus have been calculated utilising the factors specified in a separate AFRC report published in 1991. The report also identifies areas where there is a lack of research data specific to goats, recourse having to be made to published data for sheep (particularly for voluntary feed intake and the nutrient requirements of pregnancy) or cattle, as most appropriate. The review has 49 tables covering all aspects of the subject, and is fully referenced. It represents an authoritative review for advanced students, research workers and advisors in animal nutrition.

Contents:

\section{Introduction}

- The goat industry

- Goat products

- The need for information on the nutrition of the goat

Composition of Products

- Body and carcase

- Milk

- Fibre

Digestive Physiology

- Digestibility

- Rumen ammonia and rate of digestion

- Rate of passage and rumen volume

- Conclusions

Feed Intake

- Introduction

- Feeding behaviour

- Grazing

- Species comparisons : stall-feeding, minimum selection

- Published estimates of feed intake by goats

- Seasonal effects

- Water intake

- Conclusions and recommendations

Energy

- Efficiencies of utilization of metabolisable energy

- Feeding level corrections for ME intake

- Requirements for maintenance

- Requirements for activity

- Requirements for growth

- Requirements for pregnancy

- Requirements for lactation and associated live-weight changes

- Requirements for gains in body energy in lactating goats

\section{Protein}

- Energy supply for microbial synthesis in the rumen

- Feed nitrogen degradability

- Apparent efficiency of conversion of degradable dietary nitrogen into microbial nitrogen

- Microbial nitrogen yield in the rumen

- Proportion of microbial crude protein (MCP) present as microbial true protein (MTP)

- Absorbability of amino acids (AA) in the small intestine

- Digestibility of undegraded feed protein

- Efficiency of utilisation of absorbed amino acid nitrogen by ruminants

- Requirements for maintenance

- Requirements for lactation

- Requirements for growth

- Requirements for fibre

- Requirements for pregnancy

- Requirements for live-weight change in lactating goats

Minerals and Vitamins

- Mineral composition of body tissues, milk and fibre

- Calcium and phosphorus

- Magnesium

- Sodium, potassium and chloride

- Copper

- Requirements for other trace elements

- Requirements for vitamins

Production

- Rearing kids to weaning

- Nutrition of the dairy goat

- Nutrition of fibre goats

December 1997

ISBN 0851992161

$£ 22.50$ (US\$40.00)

For further information or to order please contact CAB INTERNATIONAL headquarters or an exclusive CAB INTERNATIONAL distributor in your area.

Please add $£ 2.00$ per book postage and packing (excluding $U K$ ).

CAB INTERNATIONAL

Headquarters, Wallingford, Oxon OX10 8DE, UK. Tel: (01491) 832111 Fax: (01491) 833508 E-mail: cabi@cabi.org

North America, 198 Madison Avenue, New York, NY 10016, USA. Tel: 2127266490 Fax: 2126867993 E-mail: cabi-nao@cabi.org Africa, PO Box 76520, Nairobi, Kenya. Tel: 2747 329/337 Fax: 2747340 E-mail: cabi-roaf@cabi.org

Asia, PO Box 210, 43409 UPM Serdang, Malaysia. Tel: (03) 9432921 Fax: (03) 9436400 E-mail: cabi-aro@cabi.org

Caribbean, Gordon Street, Curepe, Trinidad and Tobago. Tel: 8096457628 Fax: 8096632859 E-mail: cabi-cro@cabi.org 